\title{
Sacrifice Unacknowledged: A Literary Analysis of "The Nightingale and the Rose" by Oscar Wilde
}

\author{
Prof. EA Gamini Fonseka, PhD
}

Senior Professor in English, Department of English \& Linguistics,

University of Ruhuna, MATARA, Sri Lanka, drgamini@gmail.com

\begin{abstract}
The Nightingale in Oscar Wild's very romantic short story overhears the lamentation of the Student, who is in turmoil without knowing how he, in that wintry weather, provides a red rose for his dream sweetheart, his Professor's Daughter, who has demanded him to get one for her to match the colour of her ball dress, promising to dance with him if the latter manages. Having assessed the decisiveness of a red rose for the attainment of the Student's dream, the Nightingale embarks on a project to produce one for him, at the expense of her own life. Finally, she succeeds, but dies on the spot, as the rose blooms, absorbing her heart's flesh. The red rose equips the Student to go ahead with his plan but the Professor's Daughter, overjoyed by the jewels she has received from the Chamberlain's nephew, changes not only her ball dress but also her dance partner. She rejects the red rose along with the Student. Thrown on to the road by the frustrated Student, the red rose gets crushed under a cart wheel, manifesting the indifference of the humans. Wilde exposes through the behaviours of both the Student and the Professor's Daughter the moral decay of the Victorian society, where material objects gather prominence, undermining the ethical and moral foundations of human relationships.
\end{abstract}

KEYWORDS: Victorian England, gross materialism, class consciousness in love, human values, class-based indifference, prestige psychology, romantic sacrifice, moral frustration

\section{INTRODUCTION}

Born on October 16, 1854 in Dublin, Irish writer Oscar Wilde is well known for his novels, plays, short stories and poems, as well as for his infamous arrest and imprisonment for being gay (bio.) His rich and dramatic portrayals of the human condition came during the height of the prosperity that swept through London in the Victorian Era of the late 19th century. (Oscar Wilde Biography) According to many critics, no name is more inextricably bound to the aesthetic movement of the 1880s and 1890s in England than that of Wilde. (Poetry Foundation) Wilde wrote many short stories, plays and poems that continue to inspire millions around the world. Thereby he strived to revive some truly noble human values that used to be drifting into oblivion under the hypocrisy of Victorian morality. "The Nightingale and the Rose" is an onslaught upon the Victorian tendency to undervalue ideals that used to be reinforcing the moral and ethical superiority of the humans over the other species.

\section{Objectives, Research Problem and Significance}

The paper aims at demonstrating Wilde's exposition of class snobbery of the Victorian society by critically analyzing his short story where two humans belonging to the 19th Century elite of England fail to keep up with the altruism of a tiny bird, implying that the moral standards of the humans, affected by a capitalist value system, have drastically deteriorated to a level far below those of the other species. Wilde's symbolism conveys how the sacrifice the Nightingale makes for the sake of their love proves futile when they reduce love to a means of achieving their material ambitions. The red rose once the Professor's Daughter expects from the Student as a token of love loses its value at her hand when she receives some jewels from the Chamberlain's nephew. The red rose, when it failed to play the magic trick for the boy in winning the heart of the girl, loses its value at his hand and ends up on a road to be crushed by a cart wheel. The rose, a pristine gift from nature, with or without the involvement of the Nightingale in its production, loses its value in the presence of the corrupt values of the humans. Therefore, the study of the short story in a moralistic perspective is significant in the context of the transformations the human psyche has undergone due to industrial revolution and several other socio-economic phenomena experienced by the Victorian England.

\section{Methodology}

In order to fulfill the research requirement in developing a strong hypothesis about the moral decay experienced during the Victorian era, an attempt is made to analyze the short story under several themes significant of the developments encountered in the plot construction. So the argumentation continues under twelve subtopics: 1) The Structure of the Short Story; 2)The Student's Sorrow; 3) The Nightingale's Concern; 4) Indifference of the Other Creatures; 5) A Mission Committed to Romantic Fulfilment; 6) A Dilemma of Life and Death; 7) The Nightingale's Renunciation of Life; 8) Absence of Intuition in Institutionalized Education; 9) A Hard Sacrifice 
for Love; 10) Birth of a Red Rose; 11) Anti-climax Suggesting Class Snobbery; and 12) Conclusion: Brutal Undermining of Altruism.

\section{Results and Findings}

The outcome of the analysis of the short story depicted in twelve subtopics as in the above appears in terms of an evaluation of Wilde's genius nurtured upon his in-depth exposure to a multiplicity of disciplines known as classical and folkloric mythology, narratology, psychology, sociology, ethics, aesthetics, and culture, and his application of a wide range of literary devices such as parable, allegory, imagery, symbolism, soliloquy, dramatic irony, suspense, sarcasm, satire, and anticlimax. The findings achieved in terms of verisimilitudes suggest the boundless humanity of Oscar Wilde.

\section{The Structure of the Short Story}

The story is structured in the shape of a parable where there is an ensemble of human as well as non-human characters. Among the non-human characters there are three animate Rose-trees producing roses of three different colours. They also smoothly interact with their counterparts. So, the short story is a classic demonstration of personification and fantasy. Wilde provides a dramatic opening for the short story by verbalizing the Student's sorrow and the Nightingale's concern about the Student, and by depicting the expressions they possibly use in articulating their feelings from their respective domains. The Student's lamentation over the absence of a red rose that could win him the Professor's Daughter and the Nightingale's commiseration with the Student for his frustration without a red rose appear in alternate succession like soliloquies in a piece of theatre. The cynical remarks the other creatures make on the Student's sorrow and the Nightingale's genuine commitment to romantic fulfilment in favour of the Student clash. The Nightingale starts a mission to procure a red rose for the Student. She negotiates with the Rose-trees to obtain "a red rose" to equip the Student for the ball, where he would please his dream sweetheart. She finds the process of producing a red rose would cost her life. On calculating how it would help the Student she makes up her mind to go ahead with her mission. Yet the student misunderstands her. However, after a nightlong effort, the Nightingale succeeds in producing a marvellous rose crimson in colour, but at the cost of her life. Wilde provides a powerful formula for the creation of the rose that involves a blood transfusion from the Nightingale to the Rose-tree accompanied by melodies of different shades of love sung by her. When the red rose is complete the Student plucks it with no acknowledgement and produces it to the Professor's Daughter as a promise in a business agreement. By the time the Professor's Daughter has been presented with jewels by the Chamberlain's nephew. She rejects the Student along with the red rose, calling him "rude". Agonised by this, the Student throws away the red rose, leaving it to get crushed by a cart wheel. The Nightingale's endeavour was reciprocated by the two humans concerned in the shabbiest manner imaginable.
"This fairy tale is very incisive and, despite its apparent simplicity, leaves the reader with a clear moral message: it is important to remember that some people sometimes sacrifice their life or suffer to help others, but at the end they aren't returned with the same emotional intensity and their actions are not even fully understood" (Struzziero, 2009).

Thus, what is conveyed is a criticism of the brutal way of thinking experienced in the Victorian society, affected by materialism. Wilde makes an effort to promote sensitivity to emotions in a society where people identify each other by class. The story inspires a humanitarian approach to life.

\section{The Student's Sorrow}

The Student's sorrow is about a demand the Professor's Daughter has made, regarding his request for her to become his dance partner in the ball supposed to be given by the Prince the following night. The demand is "a red rose" to match her costume. "A red rose" is a standard symbol to express, "I love you" (www.flowerexpert.com). The young lady's demand for "a red rose" alludes to the "red roses" in the old fairy tale "Beauty and the Beast" written by Jeanne-Marie Leprince de Beaumont (1756). It is a simple demand indeed but really ominous, as ominous as the simple request that Beauty made to her father.

The Student continues to visualize how lucky he would be at the ball the following night if he could find "a red rose". Wilde soliloquizes the Student's feelings in poetic language to demonstrate the spirit of romance that exposes desires of the fashionable young people of the time. When his expressions in lyrical prose are segmented into meaningful idea-units, the lines that are broken down from the paragraph appear as an incantation in blank verse.

“The Prince gives a ball to-morrow night...

and my love will be of the company.

If I bring her a red rose, she will dance with me till dawn.

If I bring her a red rose, I shall hold her in my arms,

and she will lean her head upon my shoulder,

and her hand will be clasped in mine." (Wilde 1888)

Wilde conjures up a moment of pleasure, beauty, love, and romance through images that illustrate the elegance of the ballroom, the young lady's graceful appearance, and the romantic atmosphere the Student would enjoy with the young lady dancing "till dawn", holding her in his "arms", with "her head" lying on his "shoulder" and "her hand" "clasped" in his. Wilde provides visual, auditory, kinetic, and tactile imagery to engender the sensational pleasure the Student is dreaming of.

The image of a dancing couple formulated thus in a romantic spirit is impinged by an image of a wretched youth full of 
frustration and sorrow that contrasts with it, in the absence of "a red rose". The student visualizes how unlucky he would be at the ball the following night if he could not find "a red rose". From the joyous fantasy that emerged from the assumption of having "a red rose" the Student moves on to the sad reality predicted by the absence of "a red rose". He feels pathetic about his would-be destiny to "sit lonely" in the ball room, and watch her "pass" him "by" without any regard for him. So helpless without "a red rose" he surrenders himself to his destiny, murmuring, "my heart will break". He also imagines how she will become the most attractive and charming among the crowd of people dancing on the floor, under the inspiration of the music produced by "the harp and the violin", and indirectly expresses his jealousy of "the courtiers in their gay dresses" who "will throng round her". The volatile nature of the young lady appears in the reactions he expects from her when he appears there without "a red rose". So, the Student's worry cannot be interpreted as love. Rather it springs from his ambition to dance with a beautiful girl in the middle of an elite social gathering associated with royalties. Therefore, more than love and romance, one notices in the Student's desire, an adventure associated with class-consciousness and selfpromotion.

So helpless without "a red rose" to impress the girl he is infatuated with, the Student regrets the futility of his education. This reveals that his education has not got any elements to ensure his intellectuality and maturity as a young man.

"Ah, on what little things does happiness depend! I have read all that the wise men have written, and all the secrets of philosophy are mine, yet for want of a red rose is my life made wretched" (Wilde 1888)

Wilde ironically presents here the shortcoming of the bourgeois type education of Europe of his time. Dependence on material gifts for the sustenance of personal relationships signifies a primitive and immature level of thinking. Education basically helps to overcome materialistic desires and false values, and the student's inability to realize it suggests that his education has not helped him at all to become resilient or resistant in the presence of challenges posed by material wants and needs and vainglorious ambitions people harbour in a competitive society. He claims to have a rote memory of "all that the wise men have written" and "all the secrets of philosophy". It is absurd to consider that one can possess the knowledge represented by what one has committed to one's memory. But the Student calls them "mine". That means the education the Student talks about has been conducted on mundane concerns of everyday life. Even the bits and pieces of knowledge seem to have been collected in the light of gathering paraphernalia. Wilde ridicules the education of his time as a commercial venture dealing in spiritual objects.

\section{The Nightingale's Concern}

The young lady's demand puts the Student in a real predicament as his garden has white roses everywhere, but not a single red rose. "No red rose in all my garden!" The Student's cry reaches the Nightingale, who has "her nest in the holmoak tree" in the Student's garden. The Nightingale's deeprooted consciousness of beauty emerges in her observation of the handsome features of the Student - "his beautiful eyes filled with tears", "lips ... red as the rose of his desire", and "hair ... dark as the hyacinth-blossom"- that help her confirm, "Here at last is a true lover". She bases her position about the Student's potential to be a lover on his attractive physical features and lamentation without "a red rose" to offer his would-be sweetheart. Her sensitivity to the Student rises in her observation of the changes that have taken place on his countenance, "but passion has made his face like pale Ivory, and sorrow has set her seal upon his brow". The comparison of his dark hair to a hyacinth-blossom suggests his vulnerability through its allusion to the sad destiny of the handsome young man Hyacinthus in Greek mythology who gets killed by Apollo while learning to throw the discus. (Encyclopaedia Britannica) She demonstrates her realization that the Student is really worried about the young lady. The confession the Nightingale makes to singing of him and telling his story to the stars every night implies that, for quite some time, she has been praising the Student for his elegant personality, though he is not known to her. Wilde adds some lyrical charm to the Nightingale's voice through the repetition of the phrase, "night after night" that implies the continuity of her admiration of the Student. In classical Greek literature and even in Keats "Ode to a Nightingale" the nightingale is an eternal bird associated with things that are beautiful.

Yet the Nightingale notices a tremendous paradox in the terms of the relationship between the Student and the Professor's Daughter. She understands that the Student's failure to have "a red rose" would cost him a separation from her. In fact the Nightingale's attitude to love is far more spiritual, immaculate and natural than that of the humans. Unaffected by class or any other social values, she wonders about the worries love can precipitate for humans. She considers that all the material gifts men use to win the love of women in society, such as "emeralds", "fine opals", "pearls" and "pomegranates" are worthless. Also, she denies that love is merchandise displayed "in the marketplace", "purchased of the merchants" or "weighed out in the balance for gold". In fact, through the words of the Nightingale, Wilde attacks the institutionalization of love on the basis of class and wealth and all the materialistic values that surround the institution of marriage in terms of dowry, power, status, etc.

\section{Indifference of the Other Creatures}

The other creatures in the garden are curious about the Student's sorrow. They all ask the Nightingale, "Why is he weeping?" Yet they are not ready to share her concern. The little Green Lizard shows his curiosity while running "with his tail in the air". The Butterfly does so while "fluttering about after a sunbeam". The Daisy does so "in a soft, low voice" but 
without any commitment to help the Student. But when the Nightingale reveals that "He is weeping for a red rose," they just cry with surprise, "For a red rose?" Further, the Green Lizard cynically laughs, shouting, "how very ridiculous!" Altogether they represent the society of the Victorian England that enjoyed the grievances of the others as material for speculation. Accordingly, the Nightingale distinguishes from them all, as she is sensitive to the Student's grief as a young lover.

"But the Nightingale understood the secret of the Student's sorrow, and she sat silent in the oak-tree, and thought about the mystery of Love" (Wilde 1888).

Without following suit with the others, the Nightingale ponders upon "the mystery of Love", in the firm determination to help the Student. Wilde uses this episode, where the grotesqueness of the Lizard is prominent, to expose the moralistic hypocrisy of the Victorian upper class that had double standards and had got used to looking apathetically at the desires of the underprivileged.

\section{A Mission Committed to Romantic Fulfilment}

Wilde portrays the Nightingale as an active angel during her flight in search of a red rose for the Student. Fully resolved to help the Student, she uses her positive energy in the flight.

"Suddenly she spread her brown wings for flight, and soared into the air. She passed through the grove like a shadow, and like a shadow she sailed across the garden" (Wilde 1888).

The vivacity she demonstrates with her wings, suggests the inspiration she has drawn from love. Wilde compares her to "a shadow" while describing her movements "through the grove ... "across the garden". A shadow normally does not have a forceful impact on any object it falls on. So the Nightingale's is meant to cause no pressure on anything. Thus the Nightingale epitomizes love through her delicate behaviour.

Excited by the sight of "a beautiful Rose-tree" standing "in the centre of the grass-plot", "she flew over to it, and lit upon a spray". A "spray" in this context is "a small branch bearing buds, flowers, or berries". Therefore, it is understood that the Nightingale landed on a tiny branch of the Rose-tree. She takes no time to ask the Rose-tree for "a red rose" in exchange of her "sweetest song". In the deal the Nightingale wants to make with the Rose-tree, Wilde confers some commercial value on her song. This suggests indirectly Wilde's tremendous appreciation of nature. The response the Rose-tree makes to the Nightingale's offer suggests a long-standing reciprocity among various creatures of nature.

"My roses are white ... as white as the foam of the sea, and whiter than the snow upon the mountain. But go to my brother who grows round the old sun-dial, and perhaps he will give you what you want" (Wilde 1888).
The Rose-tree is appreciative of the Nightingale's "song" and directs her to his brother "round the old sun-dial". While assessing the whiteness of his roses, he compares them to "the foam of the sea" and claims them to excel "the snow upon the mountain".

The Nightingale's encounter with the Rose-tree "round the old sun-dial" is very much like that with the Rose-tree standing "in the centre of the grass-plot". Unfortunately, he produces yellow roses.

"My roses are yellow ... as yellow as the hair of the mermaiden who sits upon an amber throne, and yellower than the daffodil that blooms in the meadow before the mower comes with his scythe" (Wilde 1888).

The second Rose-tree respects the Nightingale's offer of her "sweetest song" and directs her to his brother "beneath the Student's window". While assessing the yellowness of his roses, he compares them to "the hair of the mermaiden who sits upon an amber throne" and claims them to excel "the daffodil that blooms in the meadow". Through the allusion to "the mower [who] comes with his scythe", Wilde suggests the humans' control on nature.

Even the Nightingale's encounter with the Rose-tree "beneath the Student's window" is very much like those with the first two Rose-trees "in the centre of the grass-plot" and "round the old sun-dial" respectively.

"My roses are red ... as red as the feet of the dove, and redder than the great fans of coral that wave and wave in the ocean-cavern" (Wilde 1888).

Like his brothers did, the Rose-tree "beneath the Student's window" also values the Nightingale's offer. While assessing the redness of his roses, he compares them to "the feet of the dove" and claims them to excel "the great fans of coral". In the Rose-tree's mention of "the ocean-cavern", Wilde establishes the oneness of nature despite the vastness of the area it has spread.

But the winter has chilled my veins, and the frost has nipped my buds, and the storm has broken my branches, and I shall have no roses at all this year" (Wilde 1888).

The complaint the Rose-tree makes here in an anaphora suggests a tragic irony. The acts of cruelty made by "the winter", "the frost", and "the storm" respectively reduce the spirit of the Rose-tree and turn his existence into a struggle.

Thus the philanthropic mission the Nightingale embarks on comes to a turning point, through the three consecutive encounters she has with three potential sources of help. The first two prove irrelevant and the third, impossible. Yet the Nightingale's courage does not leave her. On the whole this section of the story formulates a vast anaphora with a similar 
type of episodes, exchanges and figures of rhetoric. Wilde applies a sublime form of poetics to emphasize the noble intention of the Nightingale's mission.

\section{A Dilemma of Life and Death}

On hearing of the precarious condition of the Rose-tree "beneath the Student's window" the Nightingale is frustrated. In desperation, she cries, "One red rose is all I want ... only one red rose! Is there no way by which I can get it?" As she insists on it, the Rose-tree reluctantly provides a solution, but with a terrible warning. In achieving it one commits suicide.

"If you want a red rose ... you must build it out of music by moonlight, and stain it with your own heart's-blood. You must sing to me with your breast against a thorn. All night long you must sing to me, and the thorn must pierce your heart, and your life-blood must flow into my veins, and become mine" (Wilde 1888).

The method to have a red rose from the sickly Rose-tree overnight involves a magical formula. It is basically a ritual where the Nightingale, while singing in the moonlight, should get her heart pricked by a thorn of the Rose-tree and set her heart-blood to flow into the latter's veins. In modern medicine it is indeed a person to person blood transfusion. On realizing that she will die in the process of producing a red rose in this manner, she weighs the pros and cons of the sacrifice she is supposed to make in a series of parallelisms.

"Death is a great price to pay for a red rose ... and Life is very dear to all. It is pleasant to sit in the green wood, and to watch the Sun in his chariot of gold, and the Moon in her chariot of pearl. Sweet is the scent of the hawthorn, and sweet are the bluebells that hide in the valley, and the heather that blows on the hill. Yet Love is better than Life, and what is the heart of a bird compared to the heart of a man?" (Wilde 1888)

These utterances altogether form an incantation dedicated to Life that rhapsodizes Love as the culmination of all pleasures of nature. Wilde does not fail to highlight the Nightingale's consciousness that "a red rose" is not worth dying for. While she considers "Death" an unreasonable fine for such a trivial object, she considers "Life" a precious gift that allows many great pleasures. She recalls how Life allows watching from "the green wood" the majesty of the Sun and the Moon in their respective chariots - "gold" and "pearl". She recalls how Life allows the enjoyment of the fragrance of "the hawthorn", "the bluebells" and "the heather" that beautify "the hill" and "the dale". Yet she finds "the heart of a man" far superior to "the heart of a bird". Here lies the ultimate irony of the story. Thus, amidst all melancholy yet sweet recollections of a life of contentment, whether to sacrifice her life for the sake of the Student or not remains a question.

\section{The Nightingale's Renunciation of Life}

Serious about the sort of danger she is heading for, the Nightingale makes another angelic flight over the garden.
Wilde describes it using the same words he applied before as if to give a fresh beginning to the narration. He makes a pathetic portrait of the education of his time through the helpless look of the Student "still lying on the grass", whose "tears were not yet dry in his beautiful eyes". As a benefactress from heaven, the Nightingale twitters her address to the young man.

"Be happy ... be happy; you shall have your red rose. I will build it out of music by moonlight, and stain it with my own heart's blood. All that I ask of you in return is that you will be a true lover, for Love is wiser than Philosophy, though she is wise, and mightier than Power, though he is mighty. Flame-coloured are his wings, and coloured like flame is his body. His lips are sweet as honey, and his breath is like frankincense" (Wilde 1888).

"Be happy ... be happy; you shall have your red rose." The Nightingale tries to pacify the Student as if a mother does with her little son crying for a toy or a lozenge in the middle of a shopping spree. In order to get the Student to agree to a condition, she reveals the suicidal process she would follow in building the relevant red rose for him. Her condition is that the Student should be "a true lover". Talking about Love, Philosophy, and Power as characters from Greek mythology, she tries to establish Love's superiority over the other two. In her feminine identity, the Nightingale considers Love a masculine character with "flame-coloured wings", "lips [as] sweet as honey", and "breath ... like frankincense". So it is understood that the Nightingale has decided to sacrifice herself not to the person of the Student but to the character of Love in Greek mythology. Her notion of love is different from that of the humans as they consider love marketable on the basis of class, looks, education, and power and involve material objects in exchange of it. Also she has no intention to possess the person she helps to achieve his romantic dream.

\section{Absence of Intuition in Institutionalized Education}

Wilde ridicules the dogmatic outlook the Student has cultivated all his life, through the latter's inability to perceive the Nightingale's words uttered in the language of nature. $\mathrm{He}$ highlights here the artificiality of the education of his time. What the Student is unable to perceive, the Oak-tree, in whose branches the Nightingale has built her nest, perceives well. Very sad to lose her companionship, the Oak-tree whispers "Sing me one last song ... I shall feel very lonely when you are gone." Wilde signifies the melodious sweetness of her voice in a simile formed of "water bubbling from a silver jar". The student's response to the song contrasts with that of the Oaktree.

"She has form ... that cannot be denied to her; but has she got feeling? I am afraid not. In fact, she is like most artists; she is all style, without any sincerity. She would not sacrifice herself for others. She thinks merely of music, and everybody knows that the arts are selfish. Still, it must be admitted that she has some beautiful notes in her voice. What a pity it is that they do not mean anything, or do any practical good" (Wilde 1888). 
The Student betrays his intellectual and emotional handicap in the opinions he forms on the bird. Although he has some regard for her figure, he does not believe that the Nightingale is so full of empathy. He generalizes that artists are selfish and insincere and casts the Nightingale also into their category. Like the oak, the Rose-trees appreciate the "beautiful notes in her voice", but to the students they mean nothing. Thus the Student responds to the whole existence of the Nightingale in an insensitive manner. He moves into his room without any acknowledgement or praise of her song. The dreariness of the institutional education of the Victorian England emerges through his utterances like a monster that protests against the aesthetic appreciation of life. Of the totality of his behaviour in this situation, Wilde develops a paradox that highlights how the artificiality of the Victorian values prevents intuition that gives a composite perception of life and nature.

\section{A Hard Sacrifice for Love}

The moon shines in the background. The Nightingale embraces a tiny spray of the "Rose-tree beneath the window of the Student". A rose-thorn pierces her breast. The Nightingale starts singing. The "cold crystal" Moon leans down and listens. The rose-thorn goes deeper and deeper into the nightingale's breast. Her life-blood ebbs away from her suggesting a blood sacrifice. Through all these images woven together Wilde conjures up a magic ritual in a serene nocturnal atmosphere. The physical interaction between the Rose-tree and the Nightingale suggests that it is simply an overnight honeymoon. The spectacle is tinged with elements of not only beauty, romance, generosity, compassion, and courage but also those of pain, consumption, violence, and fatality. "She sang first of the birth of love in the heart of a boy and a girl." This reminds of the two adolescents in the masterpiece "The Sea Maiden" by the Victorian painter Arthur Hacker (1858-1919).

Wilde depicts a phenomenon realized in terms of "magical realism" (Rios 2015) through the "marvellous rose" that blossoms "petal after petal", as song follows song from the Nightingale's throat. He relates in fascinating terms the entire process the rose follows in gathering its shape and colour. First the rose looks "pale". In order to sound accurate about its colour, Wilde draws examples of paleness such as "the mist that hangs over the river", "the feet of the morning", and "the wings of the dawn" to depict its colour. Here he compares the morning mist to a bird or an angel white in colour. Moreover Wilde suggests its formative stage in terms of "the shadow of a rose in a mirror of silver" and "the shadow of a rose in a waterpool". Accordingly, in its paleness, the rose is only a shadow.

So engrossed in the work they have embarked on, the "Rose-tree" warns repeatedly, "Press closer, little Nightingale ... or the Day will come before the rose is finished." They are both in a fight against time. Together they strive in giving shape and colour to the rose, and the theme of the song comes to a mature stage of sexuality and love. It is not about innocent adolescent love this time but "the birth of passion in the soul of a man and a maid". The song reminds of the masterpiece "Venus and Adonis" by the Renaissance maestro Titian (15051576), where two lovers remain passionately intertwined. Still the work is going on. Wilde compares the "delicate flush of pink" that emerges from the leaves of the rose to "the flush in the face of the bridegroom when he kisses the lips of the bride". He indicates that the rose makes progress in its formation simultaneous to the progress the rose-thorn makes in reaching the Nightingale's heart.

\section{Birth of a Red Rose}

In terms of violence and pain, Wilde suggests the climax in the Nightingale's action. He denotes the moment when "the thorn touched her heart" with "a fierce pang of pain shot through her". He dramatizes the sensation of pain the Nightingale feels by emphasizing the change in the melody of her song, "Bitter, bitter was the pain, and wilder and wilder grew her song..." The change of her rhythm from the serene to the jive is meant to signal the change of the Nightingale's mood. This time the theme of her song is "the Love that is perfected by Death" and "the Love that dies not in the tomb". This binds together a series of representations of the vicissitudes that love undergoes through the stages of adolescent innocence, mature and passionate sexuality, and sacrificial death a female experiences in the process of reproduction. By and by the Nightingale's love becomes immortalized.

And the marvellous rose became crimson, like the rose of the eastern sky. Crimson was the girdle of petals, and crimson as a ruby was the heart" (Wilde 1888).

The nightlong effort flourishes in the blossom of a "marvellous" crimson rose. To say how crimson it is, Wilde compared "the heart" of the rose in "the girdle of petals" to "a ruby". The repetition of "crimson" signifies death and the ominous nature of the task.

The physical deterioration the Nightingale undergoes emerges in the symptoms she displays through her voice that "grew fainter", her wings that "began to beat", and her eyes covered by "a film". The suffocation she suffers from in her struggle to die reveals how painful it is for her to die in that way. "Then she gave one last burst of music." Wilde finishes this episode in a crescendo culminating in a bang. The violent nature of the death she experiences appears throughout her suffering. Wilde dramatizes the entire process the Nightingale follows in creating the red rose as one whole opera.

The sublime purpose of the Nightingale's sacrifice is acknowledged by the "white Moon" who "lingered on in the sky" despite "the dawn", "the red rose" who "trembled all over with ecstasy, and opened its petals to the cold morning air", Echo who "bore it to her purple cavern in the hills, and woke the sleeping shepherds from their dreams" and "the reeds of the river" who "carried its message to the sea". Echo in this situation is the nymph in Greek mythology, who rejected the love of Pan, the lustful God of shepherds and flocks, and, 
as punishment for it, underwent gang-rape by a group of shepherds. (See Chew, 2012)

The Rose-tree cries in excitement, "Look, look! ... the rose is finished now," and the Nightingale lies dead "with the thorn in her heart". It is simply a sexual suicide. The thorn is obviously a phallic symbol and it, stuck in the flesh of the Nightingale, alludes to insect mating such as that among the honey bees where the penis of the drone gets stuck in the vagina of the queen and later gets detached from his body causing his death in the end. (Armstrong 2009) In this case what is special is the Nightingale who dies is the female counterpart in the mating. The Nightingale is no more to see the masterpiece of the red rose on the Rose-tree she nurtured with her own heartblood. Together they contribute to a powerful irony.

\section{Anti-climax Suggesting Class Snobbery}

Wilde develops the episode where the Student plucks the rose with a deliberate lack of emotion. "Why, what a wonderful piece of luck!" Although it is an exclamation of thrill it conveys no feeling of gratitude or love. The only relevance it has to him lies in his belief that the Professor's Daughter will dance with him if he presents her a red rose. So, for him it is only a commodity that can be used as a token of love for the Professor's Daughter. "It is so beautiful that I am sure it has a long Latin name." So affected by his education he is worried about its botanical name rather than its beauty and fragrance. Wilde characterizes the Student as a robot rather than a human with flesh and blood. For emotions there is no room in his heart. He is as dry as dust.

The encounter between the Student and the Professor's Daughter is only a social satire, "a literary work holding up human vices and follies to ridicule or scorn" (MarianWebster). Wilde draws attention to the little dog at her feet as a symbol of class.

"You said that you would dance with me if I brought you a red rose ... Here is the reddest rose in all the world. You will wear it to-night next your heart, and as we dance together it will tell you how I love you."

"I am afraid it will not go with my dress ... and, besides, the Chamberlain's nephew has sent me some real jewels, and everybody knows that jewels cost far more than flowers."

"Well, upon my word, you are very ungrateful..."

"Ungrateful! ... I tell you what, you are very rude; and, after all, who are you? Only a Student. Why, I don't believe you have even got silver buckles to your shoes as the Chamberlain's nephew has..."

"What a silly thing Love is ... It is not half as useful as Logic, for it does not prove anything, and it is always telling one of things that are not going to happen, and making one believe things that are not true. In fact, it is quite unpractical, and, as in this age to be practical is everything. I shall go back to Philosophy and study Metaphysics" (Wilde 1888).

The boy does not have any emotions to share with the girl and he offers her the flower as a requisite procured as part of an agreement in a business transaction. He does not have any words of his own to tell her how he loves her but expects the rose to do it. The absence of a genuine expression of love makes it easy for the young lady to reject his rose and cancel her agreement. She simply states that the red rose does not go with her dress, and boastfully mentions the jewels she received from the Chamberlain's nephew, that are of more financial value than a rose. The blue silk she is rolling on a reel may have been bought to suit the jewels. So her old red dress is going to be replaced by a blue one designed to match the jewels. In the transition the Professor's Daughter makes in her choice of a colour from red to blue it can be surmised that she makes a symbolic move from sentimentality to discretion. According to David Johnson (2016), blue "causes the opposite reaction as red" and blue "can also be cold and depressing" while red "is also the colour of love". She indirectly reveals that her innocent romantic feelings are now replaced by crude materialistic values. In his agony the Student calls her "ungrateful" and the young lady retorts, calling him "rude". She even raises an issue about sartorial elegance, by referring to the silver buckles the Chamberlain's nephew has to his shoes whereas the Student has none to his. Her grotesque egoism and her physical beauty together contribute to an oxymoron such as a "lovely-looking monster". Disillusioned with the young lady's indifference he blames Love. On his way home he soliloquizes his determination to get back to "Philosophy and study Metaphysics" calling Love useless, unpractical, fickle, delusive, and outdated. Through the failure the Student makes in his approach to the young lady, Wilde indirectly criticizes the education of Victorian England which blatantly disregarded what is appreciated as emotional competence. He exposes the scholarly people's tendency to use Philosophy and Metaphysics as a camouflage to cover the limitations of their characters and uses "a great dusty book" to symbolize the grotesqueness of the whole affair of education.

\section{Conclusion: Brutal Undermining of Altruism}

Wilde uses dramatic irony to distinguish between what the reader knows about the mysterious red rose from what the Student and the Professor's Daughter know. The rose causes a commotion in nature: the Nightingale considers the Student's love to be genuine; she takes the Student's desire for a red rose seriously; she believes that the Professor's Daughter would be satisfied with a decent red rose and keep the promise she made for the Student to dance with him at the ball; she visits all rose trees in the surroundings in search of a red rose; she embarks on a painful project to produce a rose; and finally she produces a red rose at the cost of her life. The din of the "last burst of music" from the Nightingale's altruism confuses the moon and resonates over the hills and the sea, exciting the whole system of nature. It shakes the entire universe. So, the marvellous red 
rose is by all means a product of the Nightingale's altruism.

Yet it has no meaning to either the Student or the Professor's Daughter. The Professor's Daughter, enthralled by the jewels presented by the Chamberlain's nephew, considers the red rose she was once desperate to have, rubbish. The Student who finds no use in the red rose in winning the Professor's Daughter again treats it as rubbish. Disappointed by the moroseness of the Professor's Daughter, the Student "angrily ... threw the rose into the street, where it fell into the gutter, and a cartwheel went over it". Thus, the two humans, who depend on Nature for achieving a personal relationship, disappoint her, by treating her gift in the most callous manner one can ever imagine. Wilde illustrates the callousness of the Victorian class-conscious society through this simple example.

\section{REFERENCES}

1. Alberto Ríos, Department of English, Arizona State University. "Magical Realism: Definitions”. http://www.public.asu.edu/ aarios/resourcebank/ definitions/

2. Armstrong, W.P. (2009). "Sexual Suicide: Self-Destructive" Behavior in Males of Some Animals".Wayne's Word.http://waynesword.palomar.edu/ ww0701.htm

3. Artnet.“The Sea Maiden”. Arthur Hacker (British 1858-1919). http://www.artnet.com/artists/arthur-hacker/the-sea-maiden

4. Beauty and the Beast (French: La Belle et la Bête) is a traditional fairy tale written by French novelist Jeanne-Marie Leprince de Beaumont and published in 1756.

5. Bio. "Oscar Wilde Biography - Writer (1854-1900)." http://www. biography.com/people/oscar-wilde-9531078

6. Chew, K. (2012). Echo.In Gods, goddesses, and Mythology.Credo Entries. Tarrytown, NY: Marshall Cavendish Reference. Retrieved from http:// search.credoreference.com/content/entry/mcgods/echo/0

7. Oscar Wilde Biography.http://www.cmgww.com/historic/wilde/bio1.htm

8. Johnson, David (2016). "Do different colors affect your mood?" Color Psychology. http://www.infoplease.com/spot/colors1.html

9. Poetry Foundation. "Oscar Wilde - Biography." http://www. poetryfoundation.org/bio/oscar-wilde

10. Struzziero, Maria Antonietta (2009). "The Nightingale and the Rose by Oscar Wilde." "Voices and Their Echos" Atripalda: Liceo Scientifico Statale "V. De Caprariis"

11. The Flower Expert. http://www.theflowerexpert.com/content/ aboutflowers/flowermeanings/rose-flower-meanings

12. The National Gallery."Venus and Adonis."Titian (Tiziano Vecellio) (Italian, Venetian, ca. 1485/90?-1576) http://www.nationalgallery.org.uk/ paintings/workshop-of-titian-venus-and-adonis

13. Wilde, Oscar (1888). "The Nightingale and the Rose.” http://albalearning. com/audiolibros/wilde/elruisenorylarosa-en.html\#sthash.WbEkyPCQ. dpuf 